\title{
Enhanced Heterologous Protein Production in Pichia pastoris Under Increased Air Pressure
}

\author{
Marlene Lopes, Carla Oliveira, Lucília Domingues, Manuel Mota, and Isabel Belo \\ Centre of Biological Engineering, University of Minho, Campus de Gualtar, 4710-057 Braga, Portugal
}

DOI 10.1002/btpr.1964

Published online August 6, 2014 in Wiley Online Library (wileyonlinelibrary.com)

Pichia pastoris is a widely used host for the production of heterologous proteins. In this case, high cell densities are needed and oxygen is a major limiting factor. The increased air pressure could be used to improve the oxygen solubility in the medium and to reach the high oxygen demand of methanol metabolism. In this study, two P. pastoris strains producing two different recombinant proteins, one intracellular ( $\beta$-galactosidase) and other extracellular (frutalin), were used to investigate the effect of increased air pressure on yeast growth in glycerol and heterologous protein production, using the methanol AOX1-inducible system. Experiments were carried out in a stainless steel bioreactor under total air pressure of 1 bar and 5 bar. The use of an air pressure raise of up to 5 bar proved to be applicable for P. pastoris cultivation. Moreover, no effects on the kinetic growth parameters and methanol utilization (Mut) phenotype of strains were found, while an increase in recombinant $\beta$-galactosidase-specific activity (ninefold) and recombinant frutalin production was observed. Furthermore, the air pressure raise led to a reduction in the secreted protease specific activity. This work shows for the first time that the application of an air pressure of 5 bar may be used as a strategy to decrease protease secretion and improve recombinant protein production in P. pastoris. (C) 2014 American Institute of Chemical Engineers Biotechnol. Prog., 30:1040-1047, 2014

Keywords: increased air pressure, $P$. pastoris $G S 115$, P. pastoris KM71H, recombinant $\beta$-galactosidase, recombinant frutalin

\section{Introduction}

The methylotrophic yeast Pichia pastoris is currently one of the most effective and versatile systems for the production of heterologous proteins. The increasing popularity of $P$. pastoris is attributed to: (1) its powerful and tightly regulated methanol-inducible alcohol oxidase 1 promoter $(\mathrm{p} A O X 1)$ that is used to drive the expression of the foreign gene; (2) it can be easily manipulated at the molecular genetic level (e.g. gene targeting, high-frequency DNA transformation, cloning by functional complementation); (3) its ability to produce foreign proteins at high levels, intracellularly or extracellularly; (4) its capability of performing many eukaryotic posttranslational modifications, such as glycosylation, disulfide bond formation, and proteolytic processing; (5) the ability to grow on defined media at high cell densities; and (6) its strong preference for respiratory rather than fermentative mode of growth. ${ }^{1-3}$ As a result of these characteristics, to date, a large quantity of recombinant proteins have been cloned and produced in $P$. pastoris systems.

During the induction phase, Pichia pastoris cells utilize methanol through the oxidative pathway only when oxygen is non-limiting. The oxidation of methanol with molecular oxygen is the first step of both energy production and carbon assimilation. ${ }^{4}$ The literature reports the high oxygen demand

Correspondence concerning this article should be addressed to I. Belo at ibelo@deb.uminho.pt. of methanol metabolism and presumes that the oxygen limitation generally has a detrimental effect on the expression of foreign genes. 5 Thus, is crucial to keep dissolved oxygen (DO) levels above critical levels, which is achieved through agitation feedback control and by varying the oxygen content in the inlet air stream. ${ }^{3}$ However, these approaches are limited by one or more problems, such as increased cost of operational processing. Other strategies to reduce the impact of high oxygen demand during the induction phase include: (1) DO-stat processes that control the methanol feed to maintain DO concentration at a constant optimal level in the culture medium; ${ }^{3}$ and (2) low cultivation temperatures. ${ }^{6,7}$ Goldfeld et al. ${ }^{8}$ reported that methanol single dose additions maintains low oxygen consumption and reduces the oxygen transfer requirements typically associated with high cell density methanol-fed processes.

An alternative strategy that could be used to reach the large oxygen transfer rates $(O T R)$ required at the high cell densities normally achieved in $P$. pastoris cultivation is the use of increased air pressure. This is particularly important for heterologous protein production where high cell densities are reached. The $O T R$ from the gas phase into the medium is controlled by the oxygen solubility and the volumetric oxygen mass transfer coefficient $\left(K_{\mathrm{L}} \mathrm{a}\right)$. The oxygen solubility in the liquid medium can be raised by increasing the total air pressure in the cultivation system, since this parameter is affected by the oxygen partial pressure and, consequently, by the total pressure. 9,10 
Published works have reported the use of increased air pressure as a way of improving OTR that can be applied to the cultivation of yeast species such as Yarrowia lipolytica, ${ }^{11}$ Saccharomyces cerevisiae, ${ }^{12}$ Kluyveromyces marxianus, ${ }^{13}$ Candida utilis, $^{14}$ and non-recombinant $P$. pastoris. ${ }^{10}$ However, the effect of increased air and oxygen pressure is strongly dependent of the species and strains as described elsewhere. $^{15}$

Although $P$. pastoris has become a popular host for the production of industrial proteins, few studies are available on the application of air pressure increase for the cultivation of this yeast and for the production of heterologous proteins, and only slight pressure increase has been applied, namely 1.2 bar, ${ }^{16} 1.5$ bar, ${ }^{17}$ and 1.9 bar. ${ }^{18}$ Thus, this work aimed at studying the effect of higher air pressures ( 5 bar) on the production of two recombinant proteins by $P$. pastoris: the Escherichia coli $\beta$-galactosidase (produced intracellularly by the GS115 strain) and the plant lectin frutalin (secreted by the KM71H strain). In previous works, recombinant frutalin produced from the $P$. pastoris KM71H strain $^{19}$ showed a remarkable capacity as biomarker of human prostate cancer ${ }^{20}$ and as apoptosis-inducer of human cervical cancer cells in vitro. ${ }^{21}$ Therefore, it would be interesting to study new strategies to improve recombinant frutalin production to facilitate its further biomedical application. In order to achieve the goal of this work, it was important to first understand the effect of increased air pressure on the growth of the two different $P$. pastoris strains and then to address the effect on the production level of the recombinant proteins (one produced intracellularly and the other extracellularly) and on the protease release to the medium. To our knowledge, this is the first report on the production of recombinant proteins by $P$. pastoris under increased air pressure up to 5 bar. Moreover, there are no other studies about the effect of increased air pressure on protease release to the culture medium by recombinant or non-recombinant $P$. pastoris strains.

\section{Materials and Methods}

\section{Strains}

The recombinant strains $P$. pastoris GS115/pPICZ/lacZ (His $/ \mathrm{Mut}^{+}$) (Invitrogen), producing $\beta$-galactosidase intracellularly, and $P$. pastoris $\mathrm{KM} 71 \mathrm{H} / \mathrm{pPICZ} \alpha \mathrm{A} /$ frutalin $\left(\mathrm{Arg}^{+} / \mathrm{Mut}^{\mathrm{s}}\right),{ }^{19}$ producing frutalin extracellularly, were used. The production of both proteins was under the control of alcohol oxidase 1 gene promoter $(A O X 1)$ by methanol induction. The construction of the $P$. pastoris strain $\mathrm{KM} 71 \mathrm{H}$ secreting recombinant frutalin is described elsewhere. ${ }^{19}$

\section{Batch growth assays}

$P$. pastoris GS115/pPICZ/lacZ and $P$. pastoris KM71H/ $\mathrm{pPICZ} \alpha \mathrm{A} /$ frutalin strains were pre-grown overnight in $250 \mathrm{~mL}$ Erlenmeyer flasks filled with $100 \mathrm{~mL}$ of BMGH (1.34\% YNB, $1 \%$ glycerol, $4 \times 10^{-5} \%$ histidine, $400 \mathrm{mM}$ potassium phosphate buffer $\mathrm{pH}$ 6.0), and BMG $(1.34 \%$ YNB, $1 \%$ glycerol, $4 \times 10^{-5} \%$ biotin, $400 \mathrm{mM}$ potassium phosphate buffer $\mathrm{pH}$ 6.0), respectively, at $30^{\circ} \mathrm{C}$ and $200 \mathrm{rpm}$. Batch cultivations of each yeast strain were carried out using a $600 \mathrm{~mL}$ stainless steel stirred tank bioreactor (PARR 4563, Parr Instruments, USA), with $300 \mathrm{~mL}$ of $\mathrm{BMGH}$ or $\mathrm{BMG}$ medium, at $30^{\circ} \mathrm{C}$ and $400 \mathrm{rpm}$. The bioreactor was equipped with a temperature probe, a sparger tube for aeration and a pressure transducer (PARR 4842, PARR Instruments, USA). The values of air absolute pressure studied were 1 bar and 5 bar and the compressed air was continuously sparged into the culture at an aeration rate of $1 \mathrm{vvm}$.

Each experiment was replicated twice to ensure the repeatability and the reproducibility of the results.

\section{Induction assays}

The recombinant yeasts were cultivated overnight in BMGH ( $P$. pastoris GS115/pPICZ/lacZ) and BMG ( $P$. pastoris $\mathrm{KM} 71 \mathrm{H} / \mathrm{pPICZ} \alpha \mathrm{A} /$ frutalin), harvested and resuspended in fresh BMMH (same composition as BMGH but glycerol is replaced with $0.5 \%(\mathrm{w} / \mathrm{v})$ or $1 \%(\mathrm{w} / \mathrm{v})$ methanol) and $\mathrm{BMM}$ (same composition as BMG but glycerol is replaced with $0.5 \%(\mathrm{v} / \mathrm{v})$ methanol) medium, respectively. The induction assays were performed in the same stirred tank bioreactor used for batch growth assays, at $400 \mathrm{rpm}$, filled with $300 \mathrm{~mL}$ of medium, and at $30^{\circ} \mathrm{C}$ for $\beta$-galactosidase and $15^{\circ} \mathrm{C}$ for frutalin. ${ }^{19}$ Fresh methanol $(100 \%)$ to a final concentration of $0.5 \%(\mathrm{w} / \mathrm{v})$ or $1 \%(\mathrm{w} / \mathrm{v})$ was added to the medium every $12 \mathrm{~h}$ to maintain induction. The values of air absolute pressure studied were 1 bar and 5 bar with an aeration rate of $2 \mathrm{vvm}$. pH and DO was monitored offline due to the lack of $\mathrm{pH}$ and oxygen probes in the pressurized bioreactor.

Each experiment was replicated twice to ensure the repeatability and the reproducibility of the results.

\section{Analytical methods}

Culture samples were collected for analyses of cell concentration (optical density at $600 \mathrm{~nm}$ and converted to dry cell weight per litre), carbon source concentration and recombinant proteins production.

Cell viability was evaluated by the methylene blue staining method. ${ }^{22}$ Glycerol and methanol were quantified by HPLC with a Metacarb 67H column (Varian, Palo Alto, CA) and a RI detector (Knauer K-2300, Germany). The eluent was $\mathrm{H}_{2} \mathrm{SO}_{4} 0.005 \mathrm{~mol} / \mathrm{L}$ at $0.5 \mathrm{~mL} / \mathrm{min}$ and the column temperature was $60^{\circ} \mathrm{C}$, maintained with a column thermostat (Chrompack, Brasil).

$\beta$-galactosidase intracellular enzyme activity was measured after cell disruption and dialysis of cell extracts, as described elsewhere. ${ }^{13}$ The $\beta$-galactosidase activity was determined using $8.3 \mathrm{mM}$ oNPG (ortho-nitrophenyl- $\beta$-D-galactoside) in $\mathrm{Z}$ buffer $(100 \mathrm{mM}$ potassium phosphate buffer $\mathrm{pH} 7.0$ and $0.04 \mathrm{M} \beta$-mercaptoethanol) as the substrate. The release of $o$-NP ( $o$-nitrophenol) was measured by following the increase in the absorbance at $405 \mathrm{~nm}$ for $16 \mathrm{~min}$ at $37^{\circ} \mathrm{C}$. One unit of enzyme activity was defined as the amount of enzyme that release $1 \mu \mathrm{mol}$ of $o$-NP per minute under the conditions described. Total protein was determined by Bradford's method. ${ }^{23}$

Protease in cell-free samples, during frutalin induction, was quantified using $0.5 \%$ azocasein in acetate buffer as substrate at $\mathrm{pH} 5.0$, at $37^{\circ} \mathrm{C}$ for $40 \mathrm{~min}$. One unit of activity was defined as the amount of enzyme that causes an increase of 0.01 of absorbance relative to the blank per minute under assay conditions.

For the evaluation of the recombinant frutalin production, supernatants from methanol-induced cultures were separated from yeast cells by centrifugation $(10 \mathrm{~min}$ at $4000 \mathrm{~g}$ and 
Table 1. Specific Growth Rate $(\mu)$ at Exponential Growth Phase, Biomass Yield $\left(Y_{\mathrm{x} / \mathrm{s}}\right)$, and Respective Specific Substrate Consumption Rate $\left(q_{\mathrm{s}}\right)$ for $\boldsymbol{P}$. pastoris Strains Grown in Glycerol, in a Pressurized Batch Bioreactor Under 1 bar and 5 bar. Values are Average \pm Standard Deviation of Two Reproducible Fermentations

\begin{tabular}{|c|c|c|c|c|}
\hline \multirow[b]{2}{*}{ Kinetic parameters } & \multicolumn{2}{|c|}{ GS115/pPICZ/lacZ } & \multicolumn{2}{|c|}{$\mathrm{KM} 71 \mathrm{H} / \mathrm{pPICZ} \alpha \mathrm{A} /$ frutalin } \\
\hline & 1 bar & 5 bar & 1 bar & 5 bar \\
\hline$\mu\left(\mathrm{h}^{-1}\right)$ & $0.12 \pm 0.01$ & $0.12 \pm 0.01$ & $0.16 \pm 0.01$ & $0.16 \pm 0.01$ \\
\hline$Y_{\mathrm{x} / \mathrm{s}}\left(\mathrm{g} \mathrm{g}^{-1}\right)$ & $0.58 \pm 0.02$ & $0.60 \pm 0.02$ & $0.79 \pm 0.03$ & $0.73 \pm 0.02$ \\
\hline$q_{\mathrm{s}}\left(\mathrm{g} \mathrm{g}^{-1} \mathrm{~h}^{-1}\right)$ & $0.21 \pm 0.01$ & $0.20 \pm 0.01$ & $0.20 \pm 0.01$ & $0.22 \pm 0.01$ \\
\hline$O T R_{\max }\left(\mathrm{mg} \mathrm{O}_{2} / \mathrm{L} \mathrm{h}^{-1}\right)^{*}$ & \multicolumn{2}{|c|}{$\begin{array}{c}1 \mathrm{bar} \\
384\end{array}$} & \multicolumn{2}{|c|}{$\begin{array}{l}5 \text { bar } \\
1152\end{array}$} \\
\hline
\end{tabular}

*The values of $O T R_{\max }$ were obtained from Lopes et al. [10] for the same hyperbaric bioreactor used in this work.

$4^{\circ} \mathrm{C}$ ). The $\mathrm{pH}$ of the supernatants was increased to 7.5 by adding $10 \mathrm{~N} \mathrm{NaOH}$ to precipitate salts, which were removed by centrifuging twice for $10 \mathrm{~min}$ at $4000 \mathrm{~g}$ and $4{ }^{\circ} \mathrm{C}$. Treated supernatants were analyzed by SDS-PAGE with $12 \%$ gels, as described by Laemmli. ${ }^{24}$ Bands were visualized by staining with Coomassie Brilliant Blue R250. In all cases, samples were analysed in triplicate.

\section{Results and Discussion}

\section{Effect of air pressure on cellular growth and glycerol consumption}

Two recombinant $P$. pastoris strains were chosen for this work: a $P$. pastoris GS115 strain, producing intracellular $E$. coli $\beta$-galactosidase, and a $P$. pastoris $\mathrm{KM} 71 \mathrm{H}$ strain, secreting the plant lectin frutalin.

In order to understand the effect of increased air pressure on cellular batch growth on glycerol of each yeast strain, several experiments were carried out in a pressurized bioreactor under total pressure of 1 bar (equivalent to atmospheric pressure) and 5 bar. Regardless of the yeast strain, the increase of air pressure had a small effect on cellular behavior in glycerol medium with no relevant $\mathrm{pH}$ changes (less than one $\mathrm{pH}$ unit decrease with time). Thus, no inhibitory effects were observed in the cellular growth under air pressure of 5 bar as compared to 1 bar. In fact, for the two pressure conditions used, similar values of specific cellular growth rates were obtained for both strains (Table 1).

The effect of increased air pressure on cellular growth of several microbial cultures has been reported by various authors and is dependent on the microorganism and strain. While in this work no relevant effect on biomass production was observed, Charoenrat et al. ${ }^{18}$ reported a $12 \%$ enhancement on recombinant $P$. pastoris $\mathrm{Y}-11430$ final biomass under 1.9 bar of air pressure. Concerning non-recombinant yeast strains, such as Candida utilis CBS $621^{14}$ and $P$. pastoris CBS $2612^{10}$ these were also successfully cultivated with hyperbaric air, resulting in improved final biomass. However, above certain limits the increased air pressure had detrimental effects on microbial cell activity. Belo et al. ${ }^{25}$ observed an inhibition of $S$. cerevisiae cell mass production in the range of 6-15 bar of air pressure.

No relevant differences in the biomass yield per glycerol consumed were also observed in this work with the raise of air pressure up to 5 bar compared to 1 bar (Table 1). The specific glycerol consumption rate $\left(q_{\mathrm{s}}\right)$ was calculated by the ratio between the maximum specific growth rate and the biomass yield. There was no effect of increased air pressure in this parameter for both strains and a value of $0.2 \mathrm{~g} \mathrm{~g}^{-1} \mathrm{~h}^{-1}$ was obtained for all experiments (Table 1). These results may be explained by the probably high $O T R$ at 5 bar, that may exceed the oxygen demand in this substrate for the cellular density present in the culture. For instance, and according to the $q \mathrm{O}_{2}$ on glycerol $\left(128 \mathrm{mg} \mathrm{O}_{2} \mathrm{~g}^{-1} \mathrm{~h}^{-1}\right)$ reported in literature for the $P$. pastoris GS115 strain, ${ }^{26}$ for the cell densities reached in this work (around $5 \mathrm{~g} / \mathrm{L}$ of cell dry mass), the $O T R$ needed to equal the oxygen uptake rate of the culture $\left(640 \mathrm{mg} \mathrm{O}_{2} \mathrm{~L}^{-1} \mathrm{~h}^{-1}\right)$ would be between the values attained in the pressurized bioreactor at 1 bar and 5 bar (Table 1). Nevertheless, no inhibitory effects were observed in the cellular activity under 5 bar as compared to the atmospheric pressure.

\section{Effect of air pressure on recombinant protein production}

Foreign proteins expressed in $P$. pastoris are affected by a variety of factors, such as temperature, $\mathrm{pH}$, methanol feed strategy for $A O X$ inducible promoters and, particularly, the dissolved oxygen in the medium. The optimization of the use of increased air pressure as a way to improve oxygen mass transfer in Pichia cultures can represent an advantage in industrial recombinant protein production. Since stainless steel bioreactors, designed to withstand moderate pressures, are intensively applied in chemical industry, and published works have reported that the pressurization up to 5 bar can improve the energy efficiency of a STR reactor, ${ }^{9}$ the adaptation of pressurized bioreactors to microbial cultures and heterologous protein production should be not difficult.

In order to study the effect of increased air pressure on recombinant protein production, the levels of intracellular (using $\beta$-galactosidase as a model) and extracellular (using frutalin as a model) recombinant proteins produced by the respective host strains was monitored during the induction in batch cultures with methanol pulses carried out in pressurized bioreactor at 1 bar and 5 bar. Additionally, the effect of the increased air pressure on the methanol consumption rate was evaluated. According to the literature, ${ }^{3,27} \mathrm{Mut}^{+}$strains grow in methanol at the wild-type rate, requiring large quantities of it during the induction, and $\mathrm{Mut}^{\mathrm{s}}$ strains have a slow methanol utilization rate. Our results are in line with this knowledge, since the methanol consumption rate by the GS115 strain (Mut ${ }^{+}$) under 5 bar of air pressure was $0.43 \mathrm{~g} \mathrm{~L}^{-1} \mathrm{~h}^{-1}$, while for the $\mathrm{KM} 71 \mathrm{H}$ strain $\left(\mathrm{Mut}^{\mathrm{s}}\right)$ this parameter was $0.32 \mathrm{~g} \mathrm{~L}^{-1}$ $\mathrm{h}^{-1}$. Thus, increasing the air pressure up to 5 bar did not change the behavior of the strains. It is also worth of noting that no relevant effect on the biomass concentration of each recombinant strain was observed with increased air pressure up to 5 bar during the induction phase (Figure 1). Moreover, the medium $\mathrm{pH}$ remained above 5 and 4.5 , respectively, for $\beta$-galactosidase and frutalin induction cultures, indicating that cells were not stressed due to low $\mathrm{pH}$. 

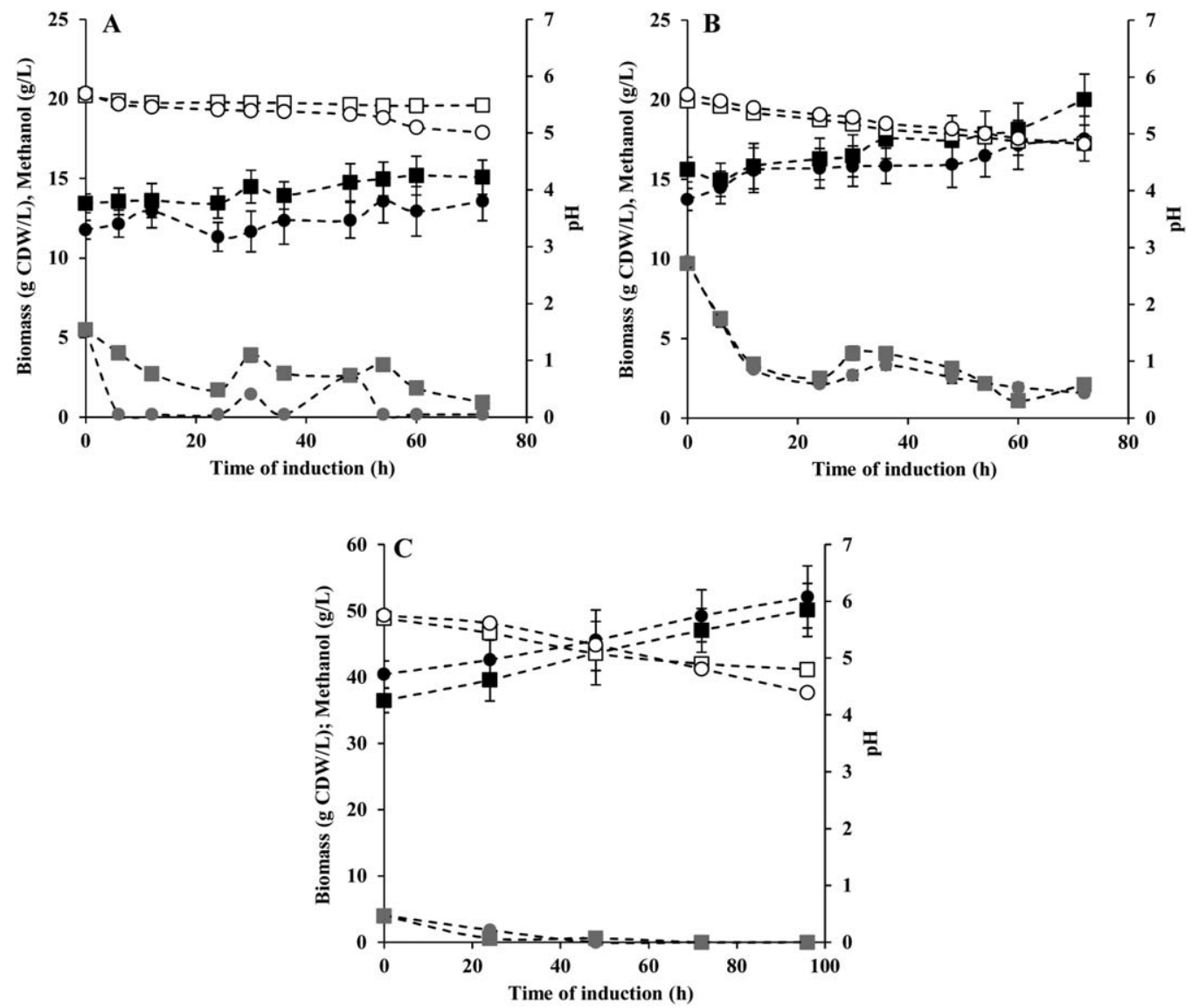

Figure 1. Biomass concentration (black symbols), methanol concentration (grey symbols), and pH (white symbols) during induction phase of (A) P. Pastoris GS115/pPICZ/lacZ with $0.5 \%$ methanol and (B) $1 \%$ methanol and (C) P. Pastoris KM71H/ pPICZ $\alpha \mathrm{A}$ /frutalin with $0.5 \%$ methanol in pressurized bioreactor under 1 bar $(\square, \square, \square)$ and 5 bar $(\bullet, \odot, \bigcirc)$ of air pressure.

Values are average \pm standard deviation of two independently run fermentation experiments.

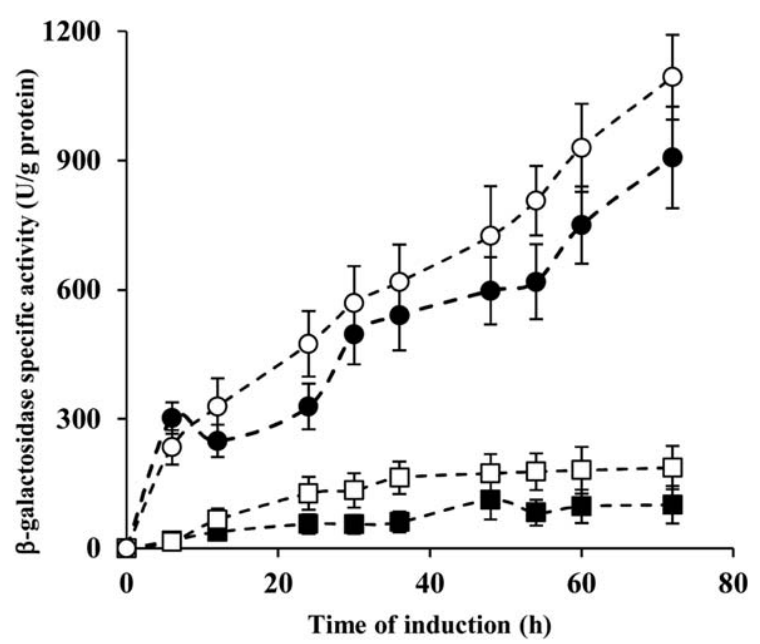

Figure 2. $\beta$-galactosidase-specific activity profiles in the cellfree intracellular extracts of $P$. pastoris GS115/ pPICZ/lacZ cultures induced with $0.5 \%(w / v)$ methanol (close symbols) and $1 \%(\mathrm{w} / \mathrm{v})$ methanol (open symbols) in the pressurized bioreactor at air pressures of 1 bar $(\square, \square)$ and 5 bar $(\odot, \bigcirc)$.

Values are the average \pm standard deviation of two independently run fermentation experiments.

For the GS115 strain, the induction assays were first performed with the addition of $0.5 \%(\mathrm{w} / \mathrm{v})$ methanol every $12 \mathrm{~h}$. As the accumulation of methanol in the medium remained lower than $5 \mathrm{~g} \mathrm{~L}^{-1}$ and $3 \mathrm{~g} \mathrm{~L}^{-1}$ in assays conducted at $1 \mathrm{bar}$ and 5 bar (Figure 1A), respectively, experiments with the addition of $1 \%(\mathrm{w} / \mathrm{v})$ methanol every $12 \mathrm{~h}$ were also performed (Figure 1B). Figure 2 shows the $\beta$-galactosidasespecific activity (U/g protein) profiles during the induction phase with both methanol concentrations.

An improvement in the enzyme specific activity was observed when the oxygen transfer rate was increased in the bioreactor due to the increased total air pressure. Raising fivefold the oxygen solubility in the medium at 5 bar, allowed to keep the dissolved oxygen concentration in the medium at least $100 \%$ saturated (measured offline at atmospheric pressure) instead of the DO values lower than $20 \%$ of saturation observed at 1 bar. At 5 bar, a 9- and 5.8-fold improvement in $\beta$-galactosidase specific activity was reached, respectively, in experiments with $0.5 \%(\mathrm{w} / \mathrm{v})$ and $1 \%(\mathrm{w} / \mathrm{v})$ methanol.

The methanol feed rate in $p A O X 1$-regulated systems is one of the most important factors to control, as the residual methanol concentration directly influences the rates of production of heterologous proteins. ${ }^{3}$ In this work, the increase of methanol addition from $0.5 \%(\mathrm{w} / \mathrm{v})$ to $1 \%(\mathrm{w} / \mathrm{v})$ to $P$. pastoris GS115 cultures led to an increment of $\beta$-galactosidase specific activity. A 1.9- and 1.2-fold improvement in enzyme specific activity was achieved in the $1 \%(\mathrm{w} / \mathrm{v})$ methanol experiments at 1 bar and 5 bar, respectively, compared to the assays with $0.5 \%(\mathrm{w} / \mathrm{v})$ methanol. It seems that the expression of foreign genes is hampered when more than 

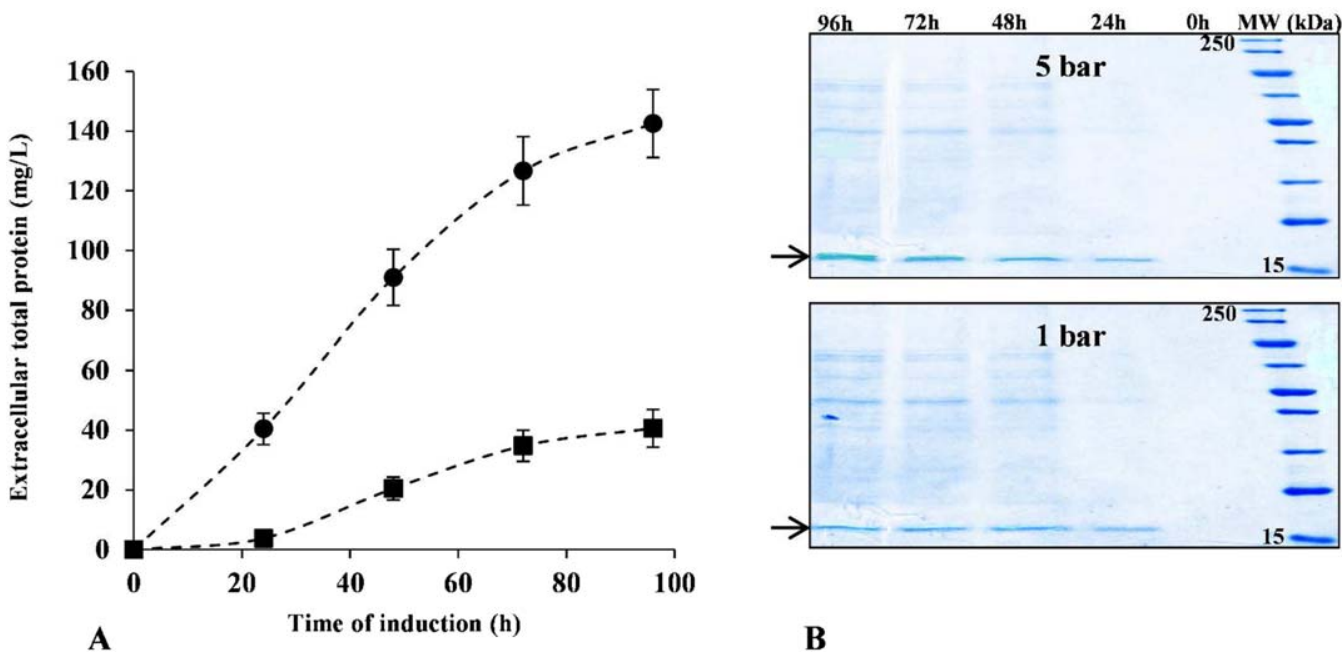

B

Figure 3. Extracellular total protein (A) and SDS-PAGE analyses (B) of supernatants from the P. pastoris KM71H strain expressing recombinant frutalin in pressurized bioreactor under 1 bar $(\square)$ and 5 bar $(\bullet)$ of air pressure.

Values in (A) are the average \pm standard deviation of two independently run fermentation experiments. The arrow indicates the recombinant frutalin.

one limiting condition is present, i.e., simultaneous limitation of methanol and oxygen. ${ }^{28}$

Recombinant frutalin was successfully expressed in $P$. pastoris as a secreted protein under the two air pressure conditions tested and could be observed in SDS-PAGE as a single band, presenting a molecular weight of about $17 \mathrm{kDa}$, as expected (Figure 3B).

Before induction, no extracellular proteins were detected in the cultures supernatants (Figures 3A, B), while the total protein concentration increased gradually until the end of the cultivation time, reaching the maximum concentration after $96 \mathrm{~h}$ of methanol induction, either at 1 bar or 5 bar of air pressure (Figure 3A). The amount of extracellular total protein released to the medium was considerably higher under increased air pressure (Figure 3A). A 3.5-fold improvement in the extracellular total protein was achieved at the end of induction phase $(96 \mathrm{~h})$ with the raise of air pressure from 1 bar to 5 bar. This enhancement of protein release to the medium was not associated to the cell lysis, once viability analyses were performed and cells remained intact and viable. The method used for the cell viability determination, the methylene blue staining method, depends on the membrane permeability, giving low viabilities as the membrane permeability increases. In this work, the cell viability remained above $90 \%$, which indicates that the raise of air pressure did not change the membrane permeability. Moreover, previous works with $Y$. lipolytica, ${ }^{11} P$. Pastoris, ${ }^{29}$ and $C$. utilis ${ }^{14}$ cells demonstrated that, for this range of pressure values, no significant differences were observed in cell viability and cell size distribution.

The major advantage of producing heterologous proteins as secreted proteins in $P$. pastoris is that it secretes very low levels of endogenous proteins. Since its culture medium contains no added proteins, the secreted heterologous protein constitutes the vast majority of the total protein in the medium. ${ }^{5}$ In this work, SDS-PAGE analyses (Coomassie Blue staining) showed that recombinant frutalin was secreted into the culture supernatant, being the main protein at 5 bar (Figure 3B). Moreover, the higher intensity of recombinant frutalin bands in the denaturing gels of the experiments under 5 bar of air pressure confirmed the increase of protein secretion comparatively to trials at 1 bar. For the experimental conditions used, the increased air pressure up to 5 bar proved to be applicable as a way to enhance the recombinant frutalin production in pressurized bioreactor.

Besides the work of Charoenrat et al. ${ }^{18}$ that reports a twofold increase on recombinant $\beta$-glucosidase production yield by $P$. pastoris $\mathrm{Y}-11430$ in a moderate pressure process $(1.9$ bar), no other studies on the effect of increased air pressure on heterologous protein secretion by $P$. pastoris can be found in the literature. In this work, the use of 5 bar resulted in a more pronounced effect on recombinant $\beta$-galactosidase production (ninefold).

The increased air pressure has already been successfully applied in the production of homologous proteins by other yeast strains. Lopes et al. ${ }^{11}$ reported an increase of 3.7-fold in the lipase productivity by $Y$. lipolytica W29 at 5 bar, compared with the experiments under 1 bar. Pinheiro et al. ${ }^{30}$ showed that it is possible to use the air pressure raise up to 6 bar as an optimization parameter for $\beta$-galactosidase production by $K$. marxianus CBS 7894. Furthermore, it was reported the enhancement of heterologous proteins production by recombinant $E$. coli strains under increased air pressure. Belo and $\mathrm{Mota}^{31}$ reported that for E. coli TB1/pUC13 cells a fourfold increase in the final productivity of cytochrome b5 was achieved by an air pressure increase of 4.8 bar.

Methanol metabolism utilizes oxygen at a high rate ${ }^{2}$ and it is well known the influence of oxygen supply on heterologous gene expression by $P$. pastoris. Some authors reported an improvement in the secretion of different heterologous proteins by maintaining sufficient oxygen levels during the induction phase. Lee et al. ${ }^{32}$ indicated that in the induction phase, maintaining a higher DO set point could significantly enhance elastase inhibiting peptide (EIP) production. Jin et al. $^{33}$ stated that with oxygen-enriched air $\left(50 \% \mathrm{O}_{2}\right)$, the effective porcine interferon-alpha $(\mathrm{pIFN}-\alpha)$ production period by recombinant $P$. pastoris $\mathrm{KM} 71 \mathrm{H}$ (IFN $\alpha$-pPICZ $\alpha \mathrm{A}$ ) could be prolonged, resulting in a further enhancement in $\mathrm{pIFN}-\alpha$ antiviral activity, comparatively to the strategy without DO control. An increase of the oxygen mass transfer rate, by raising the air pressure inside the bioreactor, is an interesting 


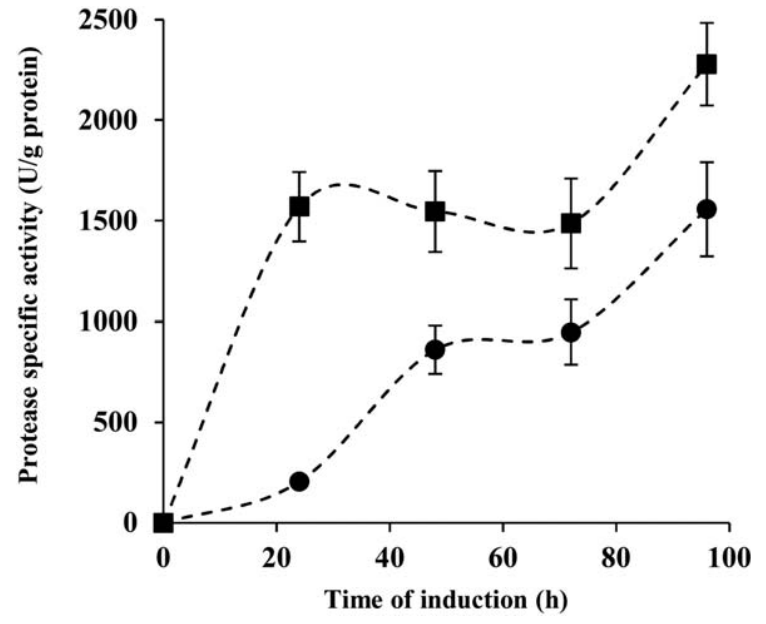

Figure 4. Protease-specific activity profiles in P. pastoris $\mathrm{KM} 71 \mathrm{H} / \mathrm{pPICZ} \alpha /$ frutalin culture supernatants, during the induction phase, in the pressurized bioreactor at different air pressures: 1 bar ( $\square$ ) and 5 bar (๑).

Values are the average \pm standard deviation of two independently run fermentation experiments.

alternative to overcome oxygen limitation. ${ }^{34}$ For instance, and according to the $q \mathrm{O}_{2}$ on methanol $\left(64 \mathrm{mg} \mathrm{O} / \mathrm{g} \mathrm{h}^{-1}\right.$ ) reported in literature for the $P$. pastoris GS115 strain, ${ }^{26}$ for the cell densities reached in this work (around $15 \mathrm{~g} / \mathrm{L}$ of cell dry mass), the OTR needed to supply to the culture (960 $\mathrm{mg} \mathrm{O}_{2} / \mathrm{L} \mathrm{h}^{-1}$ ) is significantly higher than that obtained at 1 bar (Table 1).

In this work, we proved that the raise of air pressure from 1 bar to 5 bar, as a way to increase $O T R$ in bioreactors, led to an enhancement of recombinant protein production, both intracellularly and extracellularly. This strategy is an alternative to the use of pure oxygen, which is costly and requires special handling. Moreover, Lopes et al. ${ }^{29}$ observed that $P$. pastoris cells can cope with possible oxidative stress caused by increased air pressure up to 5 bar by inducing antioxidant enzymes, such as superoxide dismutase and catalase.

\section{Effect of air pressure on protease production}

One of the major drawbacks of $P$. pastoris expression systems is the post-secretory proteolytic degradation of recombinant products. ${ }^{35}$ Some secreted proteins are unstable in the $P$. pastoris culture medium because they are rapidly degraded by proteases, which are over-expressed to the medium as a response of stress caused by methanol itself or by the transition from a given carbon source to methanol during the induction phase of $p A O X I$-regulated cultures. ${ }^{36}$ Protease specific activity (U/g protein) profiles over the induction of recombinant frutalin production from the $P$. pastoris KM71H strain are shown in Figure 4. The protease specific activity increased with time throughout the entire induction process, for both atmospheric and increased air pressure experiments. A similar result was reported by Sinha et al. $^{37}$ for a recombinant $P$. pastoris producing ovine interferon- $\tau$ at atmospheric pressure, and where the protease activity of the culture supernatant enhanced along the time and reached a maximum value (approximately $900 \mathrm{U} / \mathrm{mL}$ ) after $72 \mathrm{~h}$ of induction. However, Kobayashi et al. ${ }^{38}$ reported that, in a culture of $P$. pastoris producing the recombinant human serum albumin at atmospheric pressure, no protease activity was detected in the medium until approximately 100 $\mathrm{h}$, after which the activity strongly increased to approximately $500 \mathrm{U} / \mathrm{mL}$. This data demonstrates the variation in protease activity profiles over the course of induction in $P$. pastoris cultivation, and have been related to the cultivation conditions, especially nitrogen starvation and methanol accumulation in the medium. ${ }^{3,38}$

The highest value of protease specific activity was found for the assay conducted at $1 \mathrm{bar}$, whereas in the experiment at 5 bar its activity level in the medium was lower. Moreover, the protease specific activity profiles show that 5 bar of air pressure retards the production of protease. The presence of protease in the culture medium can influence the stability of secreted frutalin and might contribute to its higher degradation at atmospheric pressure. To our knowledge, there are no studies about the effect of increased air pressure on protease release to the culture medium by $P$. pastoris strains. However, for other yeast species, Lopes et al. ${ }^{11}$ reported that for a wild $Y$. lipolytica strain, the protease specific activity in supernatant decreased fourfold by increasing the air pressure from 4 bar to 8 bar.

It was reported that proteolytic degradation of recombinant proteins increases with protease over-expression and secretion when yeast cells are subjected to methanol-induced stress or nutrient-deficiency. ${ }^{3}$ However, in this work, the methanol concentration (Figure 1C) was negligible in any time point of the protease activity measurements for both air pressure experiments. Probably, the increase of oxygen availability at 5 bar reduced the stress caused by the $\mathrm{O}_{2}$ limitation that occurred at 1 bar, leading to a decrease on the protease released to the medium. The correlation between proteases release and stress conditions is well reported in literature. ${ }^{3,36}$

There are reports in the literature about strategies that have proven to be effective in minimizing the proteolytic degradation of recombinant proteins, namely: addition of amino-acid rich supplements, such as peptone or casamino acids $;{ }^{39}$ adjust the $\mathrm{pH}$ of the culture medium to one that is not optimal for the problem protease and reduction of induction temperature; ${ }^{6,40}$ and the use of a protease-deficient $P$. pastoris host strain (e.g., SMD1163, SMD1156, and SMD1168). ${ }^{2}$ However, in an industrial scale, the use of specific protease inhibitors has been proven to be cost-prohibitive. ${ }^{41}$ Furthermore, protease-deficient strains exhibit lower specific growth rates and viability ${ }^{5}$ and the use of these strains is not always applicable as proteases may be required for correct processing and activation of certain proteins. ${ }^{3}$

This work shows that the use of increased air pressure up to 5 bar is a feasible way to increase recombinant protein production by $P$. pastoris strains. This is a "friendly" pressure that combines several advantages, namely (a) does not relevantly affect cell viability; (b) increases oxygen mass transfer rate and, consequently, the dissolved oxygen, which is a key factor for protein production in P. pastoris; and (c) reduces the stress caused by oxygen limitation occurring at atmospheric pressure, which may be reflected as reduced protease secretion.

\section{Conclusions}

The $P$. pastoris expression system has gained acceptance as an important host organism for the production of foreign proteins, as illustrated by the large number of proteins synthesized in $P$. pastoris. Several strategies were developed in 
order to overcome the lower protein secretion and the high oxygen demand in methanol-induced cultures.

For the first time, air pressure up to 5 bar was applied for recombinant protein production improvement in $P$. pastoris. The production of intracellular ( $\beta$-galactosidase) and extracellular (frutalin) heterologous proteins were performed in $P$. pastoris GS115 and $\mathrm{KM} 71 \mathrm{H}$ strains, respectively. The raise of air pressure had similar positive effects on the production of both recombinant proteins, which indicates that pressure can be an important factor in recombinant protein production and can be used as a control parameter for heterologous protein production optimization.

The production of intracellular and extracellular recombinant proteins was enhanced by increased air pressure up to 5 bar, contrarily to what happened with cellular growth, which is an indirect evidence that oxygen demand played a greater role for recombinant protein production than for cellular growth. Furthermore, the results reported herein showed that recombinant frutalin, a lectin with a high diagnostic/therapeutic potential application, can be produced under increased air pressure in the heterologous $P$. pastoris system in higher amounts than that obtained using atmospheric pressure.

\section{Acknowledgment}

The authors acknowledge the financial support provided by FCT (grant SFRH/BD/47371/2008 to Marlene Lopes and grant SFRH/BDP/63831/2009 to Carla Oliveira), by FCT Strategic Project PEst-OE/EQB/LA0023/2013 and by the Project "BioInd - Biotechnology and Bioengineering for improved Industrial and Agro-Food processes, REF. NORTE-07-0124FEDER-000028" Co-funded by the Programa Operacional Regional do Norte (ON.2 - O Novo Norte), QREN, FEDER.

\section{Literature Cited}

1. Cereghino GPL, Cereghino JL, Christine I, Cregg JM. Production of recombinant proteins in fermenter cultures of the yeast Pichia pastoris. Curr Opin Biotech. 2002;13:329-332.

2. Cregg JM, Cereghino JL, Shi J, Higgins DR. Recombinant protein expression in Pichia pastoris. Mol Biotechnol. 2000;16:23-52.

3. Potvin G, Ahmad A, Zhang Z. Bioprocess engineering aspects of heterologous protein production in Pichia pastoris: a review. Biochem Eng J. 2012;64:91-105.

4. Baumann K, Maurer M, Dragosits M, Cos O, Ferrer P, Mattanovich D. Hypoxic fed-batch cultivation of Pichia pastoris increases specific and volumetric productivity of recombinant proteins. Biotechnol Bioeng. 2008;100:177-183.

5. Cereghino JL, Cregg JM. Heterologous protein expression in the methylotrophic yeast Pichia pastoris. FEMS Microbiol Rev. 2000;24:45-66.

6. Jahic M, Gustavsson M, Jansen A-K, Martinelle M, Enfors S-O. Analysis and control of proteolysis of a fusion protein in Pichia pastoris fed-batch processes. J Biotechnol. 2003;102:45-53.

7. Surribas A, Stahn R, Montesinos JL, Enfors S-O, Valero F, Jahic M. Production of a Rhizopus oryzae lipase from Pichia pastoris using alternative operational strategies. J Biotechnol. 2007;130:291-299.

8. Goldfeld M, Christensen J, Pollard D, Gibson ER, Olesberg JT, Koerperick EJ, Lanz K, Small GW, Arnold MA, Evans CE. Advanced near-infrared monitor for stable real-time measurement and control of Pichia pastoris bioprocesses. Biotechnol Prog. 2014;30:749-759.

9. Knoll A, Maier B, Tscherrig H, Buchs J. The oxygen mass transfer, carbon dioxide inhibition, heat removal, and the energy and cost efficiencies of high pressure fermentation. Adv Biochem Eng Biotechnol. 2005;92:77-99.
10. Lopes M, Mota M, Belo I. Batch and fed-batch growth of Pichia pastoris under increased air pressure. Biop Biosyst Eng. 2013;36:1267-1275.

11. Lopes M, Gomes N, Gonçalves C, Coelho MAZ, Mota M, Belo I. Yarrowia lipolytica lipase production enhanced by increased air pressure. Lett Appl Microbiol. 2008;46:255-260.

12. Belo I, Pinheiro R, Mota M. Fed-batch cultivation of Saccharomyces cerevisiae in a hyperbaric bioreactor. Biotechnol Prog. 2003;19:665-671.

13. Pinheiro R, Belo I, Mota M. Air pressure effects on biomass yield of two different Kluyveromyces strains. Enzyme Microb Tech. 2000;26:756-762.

14. Pinheiro R, Lopes M, Belo I, Mota M. Candida utilis metabolism and morphology under increased air pressure up to 12 bar. Process Biochem. 2014;49:374-379.

15. Lopes M, Belo I, Mota M. Over-pressurized bioreactors: application to microbial cell cultures. Biotechnol Prog. 2014;30: 767-775.

16. Woo SH, Park S-H, Lim H-K, Jung K-H. Extended operation of a pressurized $75-\mathrm{L}$ bioreactor for shLkn-1 production by Pichia pastoris using dissolved oxygen profile control. J Ind Microbiol Biotechnol. 2005;32:474-480.

17. Cunha AE, Clemente JJ, Gomes R, Pinto F, Thomaz M, Miranda S, Pinto R, Moosmayer D, Donner P, Carrondo MJT. Methanol induction optimization for $\mathrm{scFv}$ antibody fragment production in Pichia pastoris. Biotechnol Bioeng. 2004;86:458-467.

18. Charoenrat T, Ketudat-Cairns M, Jahic M, Veide A, Enfors $\mathrm{S}-\mathrm{O}$. Increased total air pressure versus oxygen limitation for enhanced oxygen transfer and product formation in a Pichia pastoris recombinant protein process. Biochem Eng J. 2006;30: 205-211.

19. Oliveira C, Felix W, Moreira RA, Teixeira JA, Domingues L. Expression of frutalin, an $\alpha$-D-galactose-binding jacalin-related lectin, in the yeast Pichia pastoris. Protein Expres Purif. 2008; 60:188-193.

20. Oliveira C, Teixeira JA, Schmitt F, Domingues L. A comparative study of recombinant and native frutalin binding to human prostate tissues. BMC Biotechnol. 2009;9:78-84.

21. Oliveira C, Nicolau A, Teixeira JA, Domingues L. Cytotoxic effects of native and recombinant frutalin, a plant galactosebinding lectin, on HeLa cervical cancer cells. J Biomed Biotechnol. 2011, doi:10.1155/2011/568932.

22. Jones R-P. Measures of yeast death and deactivation and their meaning: Part I. Process Biochem. 1987;22:118-128.

23. Bradford MM. A rapid and sensitive method for the quantification of microgram quantities of protein using the principles of protein-dye binding. Anal Biochem. 1976;72:248-255.

24. Laemmli UK. Cleavage of structural proteins during assembly of head of bacteriophage T4. Nature. 1970;227:680-685.

25. Belo I, Pinheiro R, Mota M. Morphological and physiological changes in Saccharomyces cerevisiae by oxidative stress from hyperbaric air. J Biotechnol. 2005;115:397-404.

26. Liang J, Yuan J. Oxygen transfer model in recombinant Pichia pastoris and its application in biomass estimation. Biotechnol Lett. 2007;29:27-35.

27. Çelik E, Çalık P. Production of recombinant proteins by yeast cells. Biotechnol Adv. 2012;30:1108-1118.

28. Khatri NK, Hoffmann F. Impact of methanol concentration on secreted protein production in oxygen-limited cultures of recombinant Pichia pastoris. Biotechnol Bioeng. 2006;93:871-879.

29. Lopes M, Mota M, Belo I. Comparison of Yarrowia lipolytica and Pichia pastoris cellular response to different agents of oxidative stress. Appl Biochem Biotechnol. 2013;170:448-458.

30. Pinheiro R, Belo I, Mota M. Growth and $\beta$-galactosidase activity in cultures of Kluyveromyces marxianus under increased air pressure. Lett Appl Microbiol. 2003;37:438-442.

31. Belo I, Mota M. Batch and fed-batch cultures of E. coli TBlat different oxygen transfer rates. Bioprocess Eng. 1998;18:451-455.

32. Lee CY, Lee SJ, Jung KH, Katoh S, Lee EK. High dissolved oxygen tension enhances heterologous protein expression by recombinant Pichia pastoris. Process Biochem. 2003;8: $1147-1154$

33. Jin H, Liu G, Ye X, Duan Z, Li Z, Shi Z. Enhanced porcine interferon- $\alpha$ production by recombinant Pichia pastoris with a 
combinational control strategy of low induction temperature and high dissolved oxygen concentration. Biochem Eng J. 2010;52: 91-98.

34. Lopes M, Mota M, Belo I. Oxygen mass transfer rate in a pressurized lab-scale stirred bioreactor. Chem Eng Technol 2013;36: 1779-1784.

35. Idiris A, Tohda $\mathrm{H}$, Kumagai $\mathrm{H}$, Takegawa $\mathrm{K}$. Engineering of protein secretion in yeast: strategies and impact on protein production. Appl Microbiol Biotechnol. 2010;86:403-417.

36. Yamashita S, Yurimoto Y, Murakami D, Yoshikawa M, Oku M, Sakai Y. Lag-phase autophagy in the methylotrophic yeast Pichia pastoris. Genes Cells. 2009;14:861-870.

37. Sinha J, Plantz BA, Zhang W, Gouthro M, Schlegel V, Liu C-P, Meagher M. Improved production of recombinant ovine interferon- $\tau$ by Mut ${ }^{+}$strain of Pichia pastoris using an optimized methanol feed profile. Biotechnol Prog 2003;19:794-802.

38. Kobayashi K, Kuwae S, Ohya T, Ohda T, Ohyama M, Tomomitsu K. High-level expression of recombinant human serum albumin from the methylotrophic yeast Pichia pastoris with minimal protease production and activation. $J$ Biosci Bioeng. 2000;89:55-61.

39. Cereghino GPL, Sunga AJ, Cereghino JL, Cregg JM. Expression of foreign genes in the yeast Pichia pastoris. Genet Eng. 2001; 23:57-69.

40. Viader-Salvadó JM, Castillo-Galván M, Fuentes-Garibay JA, Iracheta-Cárdenas MM, Guerrero-Olazarán M. Optimization of five environmental factors to increase beta-propeller phytase production in Pichia pastoris and impact on the physiological response of the host. Biotechnol Prog. 2013;29:1377-1385.

41. Macauley-Patrick S, Fazenda ML, McNeil B, Harvey LM. Heterologous protein production using the Pichia pastoris expression system. Yeast. 2005;22:249-270.

Manuscript received May 29, 2014, and revision received Jul. 16, 2014. 